\title{
Lactic Acidosis and Atrial Tachycardia: Unusual Presentations of Disseminated Burkitt-Like Lymphoma*
}

\author{
Hazem El-Osta ${ }^{1 \#}$, Abdulrahman Abdulbaki ${ }^{2}$, Prakash Peddi ${ }^{1}$, Amol Takalkar ${ }^{3}$, James Cotelingam ${ }^{4}$, \\ Diana Veillon ${ }^{4}$, Andres Vargas ${ }^{5}$, Nuri Akkus ${ }^{2}$, Gerhard C. Hildebrandt ${ }^{1}$ \\ ${ }^{1}$ Department of Medicine, Division of Hematology oncology, Louisiana State University Health Sciences Center, Shreveport, USA; \\ ${ }^{2}$ Department of Medicine, Division of Cardiology, Louisiana State University Health Sciences Center, Shreveport, USA; \\ ${ }^{3}$ Department of Nuclear Medicine, Louisiana State University Health Sciences Center, Shreveport, USA; ${ }^{4}$ Department of Pathology, \\ Louisiana State University Health Sciences Center, Shreveport, USA; ${ }^{5}$ Department of Medicine, Division of Internal Medicine, Lou- \\ isiana State University Health Sciences Center, Shreveport, USA. \\ Email: "helost@lsuhsc.edu
}

Received July $2^{\text {nd }}$, 2012; revised August $7^{\text {th }}$, 2012; accepted August $18^{\text {th }}, 2012$

\begin{abstract}
Lactic acidosis is a rare complication of malignancies and is seen more frequently in high grade lymphoma and leukemia. Although, its pathogenesis is not well understood, it remains a surrogate of poor prognosis. Herein, we present a case of Burkitt-like lymphoma presenting with metabolic abnormalities including lactic acidosis and hypoglycemia along with atrial tachycardia. We will discuss the different mechanisms involved in these metabolic disturbances and we will provide insight on novel therapeutic strategies based on our understanding of the underlying pathophysiology.
\end{abstract}

Keywords: Atrial Tachycardia; Burkitt-Like Lymphoma; B-Cell Lymphoma; Intra-Cardiac Tumor; Hypoglycemia; Lactic Acidosis

\section{Introduction}

Burkitt's lymphoma is a highly aggressive form of B-cell non Hodgkin lymphoma characterized pathologically by highly mitotic small non cleaved cells with round nuclei and multiple nucleoli giving a "starry-sky" pattern on histology. On molecular level, it is characterized by translocation of the c-myc gene leading to its dysregulation. It comprises 3 distinct clinical forms: endemic (African), sporadic and immunodeficiency-associated primarily seen in acquired immunodeficiency syndrome (AIDS) patients. Burkitt-like lymphoma is a morphologic variant of Burkitt's lymphoma and has pathologic features intermediate between Burkitt's lymphoma and diffuse large B cell lymphoma.

Patients with Burkitt's lymphoma present with rapidly growing masses and bulky lymphadenopathy. The endemic forms presents typically with jaw mass. On the other hand, the sporadic form presents usually with abdominal mass whereas the immunodeficiency-associated form often involves the lymph nodes.

It is often accompanied by oncologic emergencies secondary to compression by the tumor bulk, metabolic disturbances, or treatment-related hematological toxici-

\footnotetext{
*Conflict of interest: none.
}

"Corresponding author. ties. Despite its aggressive nature, response to combination chemotherapy is prompt, although associated with high risk for the development of tumor lysis syndrome.

One of the rare metabolic complications of Burkitt's lymphoma is lactic acidosis. Its underlying pathogenesis is complex and believed to be due to imbalance of lactic acid production by the tumor itself and clearance rather than hypoxia and hypoperfusion [1]. It is a surrogate of poor prognosis as described in few case reports.

\section{Case Report}

A 33-year-old female with no past medical history presented to an outside facility for 2 months history of severe weight loss, malaise and dysphagia.

She underwent an esophagogastroduodenoscopy which demonstrated a large necrotic ulcerative fungating mass in the cardia, body and lesser curvature of the stomach, of which biopsies were taken. The diagnosis of B-cell lymphoma with features intermediate between diffuse large B-cell lymphoma and Burkitt's lymphoma was made on pathology. C-myc gene rearrangement was positive on fluorescence in situ hybridization (FISH). On immunohistochemistry CD10, CD20 and leukocyte common antigen (LCA) were positive and CD3, CD5 and cyclin D1 were negative. 
Upon examination, she appeared cachectic. Pulse was $142 /$ min and regular, blood pressure 104/78 $\mathrm{mmHg}$, respiratory rate $20 / \mathrm{min}$, temperature $96.0 \mathrm{~F}$, oxygen saturation $97 \%$ on room air.

Physical exam was remarkable for oral thrush and massive left abdominal mass on palpation. No lymphadenopathy was noticed.

Her laboratory studies showed the following pertinent values (reference range): sodium $125 \mathrm{mmol} / \mathrm{L}$ (136 - 145 $\mathrm{mmol} / \mathrm{L})$, potassium $4.4 \mathrm{mmol} / \mathrm{L}(3.5-5.1 \mathrm{mmol} / \mathrm{L})$, chloride $91 \mathrm{mmol} / \mathrm{L}$ (98 - $107 \mathrm{mmol} / \mathrm{L})$, bicarbonate 17 $\mathrm{mmol} / \mathrm{L}(21$ - $32 \mathrm{mmol} / \mathrm{L})$, anion gap $17 \mathrm{mmol} / \mathrm{L}(5-15$ $\mathrm{mmol} / \mathrm{L})$, glucose $64 \mathrm{mg} / \mathrm{dl}(70-110 \mathrm{mg} / \mathrm{dL})$, creatinine $0.6 \mathrm{mg} / \mathrm{dL}$ (0.6 - $1.3 \mathrm{mg} / \mathrm{dL})$, uric acid $2 \mathrm{mg} / \mathrm{dL}$ (2.6 - 6 $\mathrm{mg} / \mathrm{dL})$, bilirubin $1.6 \mathrm{mg} / \mathrm{dL}(0.2-1 \mathrm{mg} / \mathrm{dL})$, aspartate aminotransferase (AST) $119 \mathrm{U} / \mathrm{L}(15$ - $37 \mathrm{U} / \mathrm{L})$, alanine aminotransferase (ALT) $32 \mathrm{U} / \mathrm{L}(12$ - $78 \mathrm{U} / \mathrm{L})$, lactate $11.1 \mathrm{mmol} / \mathrm{L}(0.7-2.1 \mathrm{mmol} / \mathrm{L})$, lactate dehydrogenase (LDH) 1884 U/L (84 - 246 U/L), HIV serology positive confirmed by western blot with 349494 RNA copies per $\mathrm{ml}$. Hepatitis B and C serology negative, white blood cell count (WBC) $15.7 \mathrm{~K} / \mathrm{microl}$ (3.4 - $9.2 \mathrm{~K} / \mathrm{microl}$ ), Hemoglobin $11.4 \mathrm{~g} / \mathrm{dL}(11.3-15.4 \mathrm{~g} / \mathrm{dL})$, platelet $136 \mathrm{~K} / \mathrm{microl}$ (142 - $405 \mathrm{~K} / \mathrm{microl})$, CD4 count of $83 / \mathrm{mm}^{3}$, partial thromboplastin time (PTT) $33 \mathrm{sec}(24.7-35.5 \mathrm{sec})$ and international normalized ratio (INR) 1.38. Electrocardiogram was concordant with atrial tachycardia.

She was immediately started on intravenous fluid, bicarbonate, allopurinol for tumor lysis syndrome prophylaxis and dexamethasone $40 \mathrm{mg}$ intravenous daily for 3 days. Emtricitabine/tenofovir/efavirenz was commenced for HIV and metoprolol for tachycardia, respectively.

Further work-up by echocardiogram showed a $3 \times 5$ $\mathrm{cm}$ large right atrial mass protruding to the tricuspid valve with maintained normal ejection fraction. Positron emission tomography/computed tomography scan (PET/ CT scan) indicated extensive intensely fluorodeoxyglucose (FDG) avid widespread malignant disease involving the right atrium, distal esophagus and stomach, several bowel loops, left adrenal gland, right kidney, bone marrow and possibly the intraspinal canal. Bone marrow biopsy confirmed lymphoma involvement, and spinal fluid analysis revealed presence of lymphoma cells while MRI of the brain was unremarkable.

Patient received $12 \mathrm{mg}$ of methotrexate intrathecally time one. Subsequently and after written informed consent was obtained from the patient, dose adjusted R-EPOCH multiagent chemotherapy (rituximab, etoposide, vincristine, cyclophosphamide, and doxorubicin) was initiated. Three days later, her blood counts dropped significantly with platelet of $67 \mathrm{~K} / \mathrm{microl}$, WBC of 0.79 $\mathrm{K} /$ microl and Hemoglobin of $10.2 \mathrm{~g} / \mathrm{dL}$. Her creatinine, phosphorus, potassium and uric acid remained normal, and her lactic acidosis improved with a lactate of 2.6 $\mathrm{mmol} / \mathrm{L}$. Clinically, she acutely deteriorated over the next 24 hours developing fever and severe hypotension, and was transferred to the intensive care unit. She was started on intravenous vancomycin and piperacillin/tazobactam and aggressive volume substitution. Microbiological work-up revealed positive cultures for E. coli in blood and urine, consistent with E. coli sepsis. Her clinical state further deteriorated over the next few hours, leading to acute respiratory failure, altered mental status and shock. Despite the short duration of events, in consideration of the poor overall prognosis, the family decided on do not resuscitate/Do not intubate (DNR/DNI), and the patient succumbed to gram negative sepsis 7 days after admission.

\section{Discussion}

We presented a patient with HIV-related Burkitt-like lymphoma with atrial tachycardia due to lymphomatous cardiac involvement, severe systemic extent of disease and metabolically lactic acidosis and hypoglycemia in the absence of hypoxia or hypoperfusion. Although the patient presented with tachycardia and elevated white count, the negativity of blood cultures upon admission along with the improvement of the lactic acidosis after treatment with chemotherapy are arguments that favor lymphoma as a cause of the lactic acidosis rather than an underlying sepsis. Our case underscores few particular observations. Although rarely described, lactic acidosis without evidence for hypoxia or hypoperfusion can point towards an underlying hematological malignancy and prompt diagnosis and early treatment of underlying etiology potentially improves outcome. The underlying pathophysiology of lactic acidosis in these patients is not yet fully understood. Several mechanisms have been postulated including 1) overproduction of lactic acid by tumor cells through an upregulation of enzymes involved in aerobic glycolysis, through a highly proliferative tumor in mismatch with needed tumor blood supply leading to tumor cell hypoxia and increased anaerobic glycollysis [1-5], and it was also suggested, that lactic acidosis is simply the result of bulk of disease rather than an increase of lactic acid at a cellular level [6]; 2) Impaired hepatic and renal clearance of lactic acid [1,5]; 3) Microvascular embolization of tumor cells causing a state of tissue hypoperfusion and therefore leading to anaerobic glycolysis [5,7]; 4) Thiamine deficiency leading to a reduction in the pyruvate dehydrogenase activity and consequently to accumulation of pyruvate which will be converted to lactate [8].

The treatment of malignancy-associated lactic acidosis is mainly empirical and based on few case reports and case series. Acidosis is often responsive to aggressive chemotherapy $[1,5,9,10]$, although this does not seem to affect the clinical outcome as illustrated in our patient and previous reported cased described in Table 1. Che- 
Table 1. Table summarizing the characteristics and outcomes of reported cases of Burkitt and Burkitt-like lymphoma associated with lactic acidosis.

\begin{tabular}{|c|c|c|c|c|c|c|c|c|c|c|}
\hline Case & Age & Sex & Presenting sign & $\begin{array}{c}\text { HIV } \\
\text { status }\end{array}$ & Glycemia & $\begin{array}{c}\text { Lactate } \\
\text { peak }\end{array}$ & $\begin{array}{c}\text { Lactic acidosis } \\
\text { resolution }\end{array}$ & $\begin{array}{c}\text { Treatment } \\
\text { received }\end{array}$ & Outcome & Comment \\
\hline $\begin{array}{c}\text { Block J. B. } \\
\text { et al. [2] } \\
\text { (1966) }\end{array}$ & 27 & $\mathrm{~F}$ & $\begin{array}{l}\text { Ascites, pleural } \\
\text { effusion }\end{array}$ & NR & Normal & 3.55 & Yes & $\begin{array}{l}\text { Nitrogen mustard, } \\
\text { vincristine, } \\
\text { prednisone, } \\
\text { ibenzmethyzin }\end{array}$ & $\begin{array}{l}\text { Died in } \\
3 \text { months }\end{array}$ & $\begin{array}{l}\text { Increased } \\
\text { lactate in } \\
\text { pleural fluid }\end{array}$ \\
\hline $\begin{array}{l}\text { Rouzet P. } \\
\text { et al. [19] } \\
(1991)\end{array}$ & 8 & $\mathrm{M}$ & $\begin{array}{l}\text { Small bowel } \\
\text { obstruction }\end{array}$ & NR & Normal & 139 & Yes & LMB-84 & $\begin{array}{c}\text { Alive after } \\
2.5 \text { years }\end{array}$ & $\begin{array}{l}\text { LA responded } \\
\text { quickly to } \\
\text { thiamine }\end{array}$ \\
\hline $\begin{array}{l}\text { Bergin C. } \\
\text { et al. [17] } \\
(1993)\end{array}$ & 26 & M & $\begin{array}{l}\text { Constitutional } \\
\text { symptoms }\end{array}$ & positive & Mildly low & 12.2 & $\begin{array}{c}\text { Slight } \\
\text { improvement } \\
\text { (decreased to 7.9) }\end{array}$ & $\begin{array}{l}\text { Combination } \\
\text { chemotherapy } \\
\text { (not specified) }\end{array}$ & $\begin{array}{l}\text { Died in } \\
7 \text { days }\end{array}$ & \\
\hline $\begin{array}{l}\text { Revesz T. } \\
\text { et al. }[16] \\
(1995)\end{array}$ & 8 & M & $\begin{array}{l}\text { Seizure, diabetes } \\
\text { insipidus }\end{array}$ & NR & Normal & 24 & $\begin{array}{c}\text { Improved } \\
\text { (decreased to 6.2) }\end{array}$ & $\begin{array}{l}\text { Etoposide, } \\
\text { steroid, XRT }\end{array}$ & $\begin{array}{c}\text { Died in } \\
4 \text { months } \\
\text { after relapse }\end{array}$ & $\begin{array}{c}\text { Kidney } \\
\text { involvement }\end{array}$ \\
\hline $\begin{array}{c}\text { Megarbane B. } \\
\text { et al. [18] } \\
(2000)\end{array}$ & 77 & M & $\begin{array}{c}\text { Fever of unknown } \\
\text { origin, SIRS }\end{array}$ & NR & Normal & 27 & Yes & $\begin{array}{l}\text { CVP, intrathecal } \\
\text { chemo }\end{array}$ & $\begin{array}{l}\text { Died from } \\
\text { sepsis }\end{array}$ & \\
\hline $\begin{array}{c}\text { Glasheen J. } \\
\text { et al. [14] } \\
\text { (2005) }\end{array}$ & 74 & $\mathrm{M}$ & $\begin{array}{l}\text { Pleural effusion, } \\
\text { right sided edema }\end{array}$ & NR & Low & 15.8 & NR & None & $\begin{array}{l}\text { Died in } \\
13 \text { days }\end{array}$ & \\
\hline $\begin{array}{l}\text { Lopez- } \\
\text { Rodriguez M. } \\
\text { et al. [15] } \\
\text { (2007) }\end{array}$ & 33 & $\mathrm{M}$ & Back pain & Positive & Low & 8.41 & NR & None & $\begin{array}{l}\text { Died in } \\
7 \text { days }\end{array}$ & \\
\hline $\begin{array}{l}\text { Rastogi M. } \\
\text { et al. [21] } \\
\text { (2008) }\end{array}$ & 11 & $\mathrm{M}$ & $\begin{array}{l}\text { Fever, } \\
\text { edema, } \\
\text { rash }\end{array}$ & Positive & $\begin{array}{c}\text { Intractable } \\
\text { hypoglycemia }\end{array}$ & 15.2 & $\begin{array}{l}\text { Decreased } \\
\text { to } 9.6\end{array}$ & None & $\begin{array}{l}\text { Death in } \\
33 \text { days }\end{array}$ & $\begin{array}{c}\text { Received } \\
\text { glucagon for } \\
\text { hypoglycemia }\end{array}$ \\
\hline $\begin{array}{l}\text { Kulkarni K. } \\
\text { et al. [20] } \\
\text { (2010) }\end{array}$ & 12 & $\mathrm{M}$ & $\begin{array}{c}\text { Abdominal } \\
\text { pain, weakness }\end{array}$ & Negative & Normal & 21 & Yes & MCP-842 & $\begin{array}{l}\text { Recovery } \\
\text { (unspecified } \\
\text { follow-up) }\end{array}$ & $\begin{array}{c}\text { Elevated } \\
\text { triglyceridemia }\end{array}$ \\
\hline Present report & 33 & $\mathrm{~F}$ & $\begin{array}{l}\text { Constitutional } \\
\text { symptoms, } \\
\text { dysphagia, atrial } \\
\text { tachycardia }\end{array}$ & Positive & Low & 11.1 & Improved to 2.6 & R-EPOCH & $\begin{array}{l}\text { Died in } \\
7 \text { days }\end{array}$ & \\
\hline
\end{tabular}

CVP: cyclophosphamide, vincristine and prednisone; LMP-84: intensive combination chemotherapy protocol containing vincristine, cyclophosphamide, prednisone, doxorubicin, high dose methotrexate and cytarabine; MCP-842: ifosfamide-based, moderately intensive short-duration combination chemotherapy protocol; NR: not reported; R-EPOCH: chemotherapy protocol containing rituximab, etoposide, vincristine, cyclophosphamide, doxorubicin and prednisone; XRT: radiation therapy.

motherapy seems to exert its effect by cytoreduction of tumor cells leading to decreased production of lactic acid and in cases of liver involvement to improved lactic acid clearance. Renal dialysis can be useful in some cases $[1,5,9,10]$. Resolution of lactic acidosis with thiamine repletion has been described previously in lymphoma [8]; however it did not have any effect on lactic acid level in Burkitt's lymphoma.

Amid the uncertainty in the optimal management of this condition, a better recognition of the different mechanisms involved in lactic acidosis of hematological malignancies is needed. For instance, anecdotal reports have found elevated IGF1 and TNFalpha levels in a lymphoma patient with lactic acidosis [1]. Although no causality link could be established between an increase in insulin growth factor 1 (IGF-1) and development of lactic acidosis, this is an interesting observation since IGF-1 induces the expression of hexokinase which results in high rates of glycolysis and pyruvate production $[3,4]$. On the other hand, tumor necrosis factor alpha (TNF alpha) leads to reduced activity of pyruvate dehydrogenase and subsequently increased conversion of pyruvate into lactate [11]. Accordingly, it can be postulated that the IGF1 pathway can work in concert with TNF alpha to increase lactic acid production. Importantly, IGF1 signaling is implicated in many types of cancers [12]. Several IGF targeting agents are in early clinical trials and have shown promising results [13]. It will be important to test whether lactic acidosis in lymphoma is a reflection of an underlying overactivated IGF-1 pathway that can drive tumor cell proliferation, and to determine whether IGF-1, TNF and maybe other candidate pathways are valuable therapeutic targets that could change the disease's outcome.

Lactic acidosis associated with Burkitt-like lymphoma portends an extremely poor prognosis. Among the 10 
reported cases including our case, 8 patients had a fatal outcome, with death occurring in a matter of days to weeks from the onset of lactic acidosis. In only one case, the patient was alive after 2.5 years of diagnosis and in another case the outcome was not well specified (Table 1) [2,14-21].

Using FDG-PET/CT, generally FDG uptake is strong in myocardium and brain. In our patient, the pattern of FDG metabolic distribution demonstrated less uptake in these tissues than usually observed, whereas significant FDG uptake was seen in the lymphoma spread throughout the body. This observation eludes to an indirect visual insight into one potential mechanism of hypoglycemia in lymphoma, as it suggests an increase in glucose uptake by tumor cells as a possible contributor of systemic hypoglycemia.

Our case illustrates the complementarities of multimodality imaging in assessing cardiac involvement by Burkitt-like lymphoma. The sensitivity and specificity of FDG PET/CT scan for detection of extranodal Burkittlike lymphoma are $100 \%$ and $94 \%$ respectively, and few

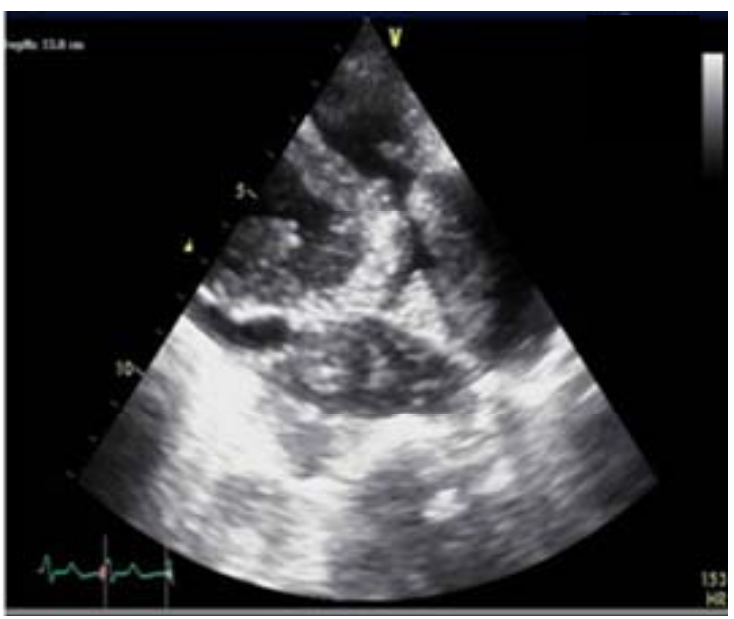

(a)

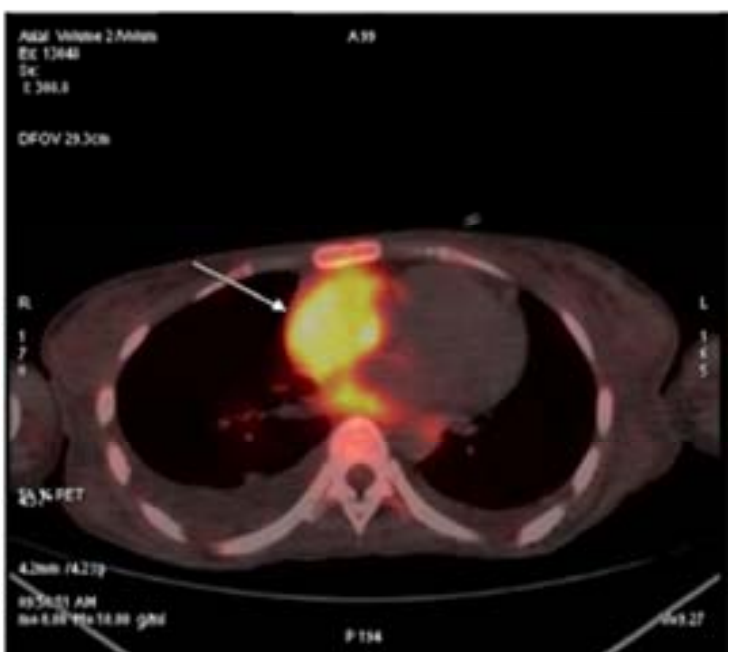

(b)

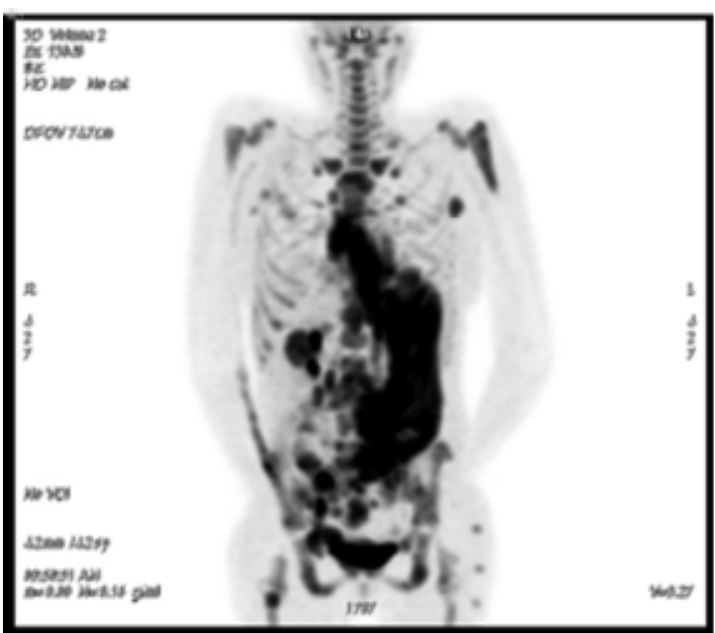

(c)

Figure 1. (a) echocardiogram demonstrating a right ventricular Inflow track showing the right atrial mass which extends to the tricuspid valve. (b) PET/CT scan showing an intensively FDG avid lesion in the right atrium corresponding to the lesion seen on echocardiogram. (c) PET scan indicating diffusely intense FDG uptake consistent with extensive disease.

reports have shown its utility to detect intra-cardiac and myocardial involvement $[22,23]$. In our case, FDG-PET/ CT provided imaging confirmation of echocardiographic findings of a right atrial mass, and in addition its metabolic activity provided crucial clues on the lymphomatous origin versus non-metabolically active lesion such as thrombus (Figure 1).

Intra-cardiac tumors presenting as arrhythmia were reported in left atrial myxoma, and intracardiac follicular B cell lymphoma, the latter mostly reported as atrial flutter [24-28]. To our knowledge this is the first reported case of intracardiac metastatic Burkitt-like lymphoma presenting as atrial tachycardia, which emphasizes a meticulous work-up in patients with malignancies for cardiac involvement in the presence of diagnostic or clinical abnormalities.

\section{Conclusion}

Lactic acidosis associated with Burkitt-like lymphoma is a rare and life threatening medical condition. It results from the imbalance between increase lactic acid production and decreased lactic acid clearance. Determination of lactic acid level in patients with aggressive lymphoma and elevated anion gap is warranted for early detection and treatment of this condition. Treatment of the underlying hematologic malignancy by chemotherapy can lead in some cases to resolution of lactic acidosis but the final outcome is almost invariably fatal. A better understanding of lactic acidosis pathophysiology in the setting of cancer will hopefully translate into improved 
therapeutic modalities.

\section{REFERENCES}

[1] E. M. Sillos, J. L. Shenep, G. A. Burghen, C. H. Pui, F. G. Behm and J. T. Sandlund, "Lactic Acidosis: A Metabolic Complication of Hematologic Malignancies: Case Report and Review of the Literature,” Cancer, Vol. 92, No. 9, 2001, pp. 2237-2246. doi:10.1002/1097-0142(20011101)92:9<2237::AID-CNC R1569>3.0.CO;2-9

[2] J. Block, W. Bronson and W. Bell, "Metabolic Abnormalities of Lactic Acid in Burkitt-type Lymphoma with Malignant Effusion,” Annals of Internal Medicine, Vol. 65, No. 1, 1966, pp. 101-108.

[3] S. Sebastian and U. W. Kenkare, "Insulin-Like Growth Factor 1 Induces Tumor Hexokinase RNA Expression in Cancer Cell," Biochemical and Biophysical Research Communications, Vol. 235, No. 2, 1997, pp. 389-393. doi:10.1006/bbrc.1997.6797

[4] S. P. Mathupala, A. Rempel, P. L. Pedersen, “Aberrant Glycolytic Metabolism of Cancer Cells: A Remarkable Coordination of Genetic, Transcriptional, Post-Translational, and Mutational Events that Lead to a Critical Role for Type II Hexokinase,” Journal of Bioenergetics and Biomembranes, Vol. 29, No. 4, 1997, pp. 339-343. doi:10.1023/A:1022494613613

[5] J. P. Ruiz, A. K. Singh and P. Hart, "Type B Lactic Acidosis Secondary to Malignancy: Case Report, Review of Published Cases, Insights into Pathogenesis, and Prospects for Therapy,” The Scientific World Journal, Vol. 11, 2011, pp. 1316-1324.doi:10.1100/tsw.2011.125

[6] S. Sariban-Sohraby, I. T. Magrath and R. S. Balaban, "Comparison of Energy Metabolism in Human Normal and Neoplastic (Burkitt's Lymphoma) Lymphoid Cells," Cancer Research, Vol. 43, No. 10, 1983, pp. 4662-4664.

[7] R. G. Narins, G. G. Krishna, J. Yee, et al., "The Metabolic Acidosis,” In: R. G. Narins, Ed., Maxwell \& Kleeman's Clinical Disorders of Fluid and Electrolyte Metabolism, 5th Edition, McGraw-Hill, Inc., New York, 1994, pp. 769-825

[8] J. Svahn, M. Schiaffino, U. Caruso, M. Calvillo, G. Minniti and C. Dufour, "Type B Lactic Acidosis Secondary to Malignancy: Case Report, Review of Published Cases, Insights into Pathogenesis, and Prospects for Therapy," Journal of Pediatric Hematology/Oncology, Vol. 25, 2003, pp. 965-968. doi:10.1097/00043426-200312000-00012

[9] S. Osorio, C. Bernis and R. de La Camara, "Lactic Acidosis in Non-Hodgkin's Lymphoma and Response to Chemotherapy,” Haematologica, Vol. 87, No. 2, 2002, p. 5

[10] A. S. Friedenberg, D. E. Brandoff and F. J. Schiffman, “Type B Lactic Acidosis as a Severe Metabolic Complication in Lymphoma and Leukemia: A Case Series from a Single Institution and Literature Review," Medicine (Baltimore), Vol. 86, No. 4, 2007, pp. 225-232. doi:10.1097/MD.0b013e318125759a

[11] J. Durig, W. Fiedler, M. de Wit, M. Steffen and D. Hossfeld, "Lactic Acidosis and Hypoglycemia in a Patient with High-Grade Non-Hodgkin's Lymphoma and Elevated Circulating TNF-a," Annals of Hematology, Vol. 72, No. 2, 1996, pp. 97-99. doi:10.1007/BF00641317

[12] H. Werner and D. LeRoith, "The Role of the Insulin-Like Growth Factor System in Human Cancer,” Advances in Cancer Research, Vol. 68, 1996, pp. 183-223. doi:10.1016/S0065-230X(08)60354-1

[13] T. A. Yap, D. Olmos, L. R. Molife and J. S. de Bono, "Targeting the Insulin-Like Growth Factor Signaling Pathway: Figitumumab and Other Novel Anticancer Strategies,” Expert Opinion Investigatinal Drugs, Vol. 20, No. 9, 2011, pp. 1293-1304. doi:10.1517/13543784.2011.602630

[14] J. J. Glasheen and M. D. Sorensen, “Burkitt’s Lymphoma Presenting with Lactic Acidosis and Hypoglycemia-A Case Presentation,” Leukemia \& Lymphoma, Vol. 46, No. 2, 2005, pp. 281-283. doi:10.1080/10428190400016723

[15] M. López Rodríguez, E. Vázquez Muñoz, J. Gómez Cerezo, B. Pagán Muñoz, E. Ruiz Bravo-Burguillos, F. J. Barbado Hernández, "Lactic Acidosis, Severe Hypoglycemia and Hepatosplenomegaly,” Revista Clínica Española, Vol. 207, No. 10, 2007, pp. 521-522. doi:10.1157/13111552

[16] T. Révész, K. Obeid and C. Mpofu, "Severe Lactic Acidosis and Renal Involvement in a Patient with Relapsed Burkitt's Lymphoma," Journal of Pediatric Hematology/Oncology, Vol. 12, No. 3, 1995, pp. 283-288. doi:10.3109/08880019509029570

[17] C. Bergin, R. Pilkington, C. McCreary, F. Mulcahy and V. Crowley, "Lactic Acidosis, Non-Hodgkins Lymphoma and the Acquired Immunodeficiency Syndrome," Genitourinary Medicine, Vol. 70, No. 2, 1994, pp. 148-149. doi:10.1136/sti.70.2.148

[18] B. Mégarbane, F. Bruneel, V. Andrieu, M. Wolff and B. Régnier, “The Last Voyage of a Globe-Trotter," La Revue de Médecine Interne, Vol. 21, Suppl. 3, 2000, pp. 340s342s. doi:10.1016/S0248-8663(00)89263-2

[19] P. Rouzet, H. Rubie, A. Robert, A. Dutour, J. P. Olives, C. Scipioni, J. Guitard and C. Régnier, "Severe Hyperlactacidemia in 2 Children Treated for Malignant Tumors. Role of Vitamin B1,” Archives Francaises de Pédiatrie, Vol. 48, No. 6, 1991, pp. 423-426.

[20] K. Kulkarni, S. Kaur, A. Sibal, N. Jerath and L. S. Arya, "Severe Lactic Acidosis, Hypertriglyceridemia, and Extensive Axial Skeleton Involvement in a Case of Disseminated Burkitt's Lymphoma," International Journal of Hematology, Vol. 91, No. 3, 2010, pp. 546-548. doi:10.1007/s12185-010-0534-8

[21] M. V. Rastogi, N. Desai and J. B. Quintos, "Non-IsletCell Tumor Hypoglycemia and Lactic Acidosis in a Child with Congenital HIV and Burkitt's Lymphoma,” Journal of Pediatric Endocrinology \& Metabolism, Vol. 21, No. 8, 2008, pp. 805-810. doi:10.1515/JPEM.2008.21.8.805

[22] D. Karantanis, J. M. Durski, V. J. Lowe, M. A. Nathan, B. P. Mullan, E. Georgiou, P. B. Johnston and G. A. Wiseman, "18F-FDG PET and PET/CT in Burkitt's Lymphoma,” European Journal of Radiology, Vol. 75, No. 1, 2010, pp. e68-e73. doi:10.1016/j.ejrad.2009.07.035

[23] K. K. Poh, R. C. Cury, J. Solis, A. J. Fischman, M. J. 
Wood, "Images in Cardiovascular Medicine. Complementary Role of Multimodality Imaging in the Evaluation of Intracardiac Lymphoma in an HIV-Infected Man,” Circulation, Vol. 115, No. 12, 2007, pp. e339-e341. doi:10.1161/CIRCULATIONAHA.106.664177

[24] D. Mioulet, L. Braem, P. Heno, P. Paule, J. M. Peloni, D. Bonnet and L. Fourcade, "Cardiac Extension of a NonHodgkin Lymphoma Revealed by an Atrial Flutter," Annales de Cardiologie et d'Angéiologie, Vol. 58, No. 2, 2009, pp. 117-121. doi:10.1016/j.ancard.2008.05.007

[25] E. Abinader and S. Rauchfleisch, "Left Atrial Myoma Presenting with Atrial Tachycardia,” Harefuah, Vol. 105, No. 9, 1983, pp. 263-264.

[26] M. Linhart, L. Lickfett, C. Hammerstingl, K. Tiemann, G.
Nickenig and T. Lewalter, "Paroxysmal Atrial Flutter Caused by Cardiac Lymphoma," Pacing and Clinical Electrophysiology, Vol. 29, No. 6, 2006, pp. 682-684. doi:10.1111/j.1540-8159.2006.00419.x

[27] M. A. Thompson, A. Harker-Murray, A. J. Lockets and P. Chareonthaitawee, "Unusual Lymphoma Manifestations: Case 2. Myocardial Lymphoma Presenting as Atrial Flutter,” Journal of Clinical Oncology, Vol. 22, No. 3, 2004, pp. 558-560. doi:10.1200/JCO.2004.12.100

[28] D. Hayes Jr., D. K. M. Liles and V. L. Sorrell, “An Unusual Cause of New-Onset Atrial Flutter: Primary Cardiac Lymphoma,” Southern Medical Journal, Vol. 96, No. 8, 2003, pp. 799-802.

doi:10.1097/01.SMJ.0000054225.89526.BD 